\title{
Characterizing the deep insular shelf coral reef habitat of the Hind Bank Marine Conservation District (US Virgin Islands) using the Seabed Autonomous Underwater Vehicle
}

Roy A. Armstrong ${ }^{1}$, Hanumant Singh ${ }^{2}$, Juan Torres ${ }^{1}$, Richard S. Nemeth ${ }^{3}$ Ali Can ${ }^{2}$, Chris Roman ${ }^{2}$, Ryan Eustice $^{2}$, Lauren Riggs ${ }^{4}$, and Graciela Garcia-Moliner ${ }^{1,5}$

${ }^{1}$ Bio-optical Oceanography Laboratory, University of Puerto Rico, Mayagüez, PR 00681-9013

${ }^{2}$ Department of Applied Ocean Physics and Engineering, Woods Hole Oceanographic Institution, Woods Hole, MA 02543-1109

${ }^{3}$ Center for Marine and Environmental Studies, University of the Virgin Islands, St. Thomas, USVI, 00802

${ }^{4}$ Economics and Environmental Studies Program, Saint Mary's College of Maryland, Saint Mary's City, MD 20686

${ }^{5}$ Caribbean Fishery Management Council, 268 Muñoz Rivera Ave., Suite 1108, San Juan, PR 00918

*Corresponding author: Roy A. Armstrong, tel. (787) 899-6875, fax: (787) 899-5500, email: roy@cacique.uprm.edu 


\begin{abstract}
The benthic communities of the deep insular shelf at the Hind Bank Marine Conservation District (MCD), an important spawning grouper aggregation site, were studied with the Seabed autonomous underwater vehicle (AUV) at depths between 32 to $54 \mathrm{~m}$. Four digital phototransects provided data on benthic species composition and abundance of the insular shelf off St. Thomas, U.S. Virgin Islands. Within the western side of the MCD, welldeveloped coral reefs with $43 \%$ mean living coral cover were found. The Montastrea annularis complex was dominant at all four sites between 33 to 47 $\mathrm{m}$, the depth range where reefs were present. Maximum coral cover found was $70 \%$ at depths of 38 to $40 \mathrm{~m}$. Quantitative determinations of sessile-benthic populations, as well as the presence of motile-megabenthic invertebrates and algae were obtained. The Seabed AUV provided new quantitative and descriptive information of a unique coral reef habitat found within this deeper insular shelf area.
\end{abstract}

Keywords: Atlantic; U.S. Virgin Islands; Coral reef; Deep hermatypic corals; AUV 


\section{Introduction}

Shallow coral reefs in the tropical West Atlantic Ocean have experienced living coral cover declines of up to $80 \%$ in the last 30 years (Gardner et al., 2003). Pollution, sedimentation, hurricanes, and coral disease are all contributors to the decline in living coral cover. While numerous assessments of coral reef habitat have been conducted throughout the tropical western Atlantic and elsewhere using SCUBA, there is limited information on the deeper reefs zones, up to $100 \mathrm{~m}$, which lie beyond the range of safe diving operations. Mapping and monitoring deeper hermatypic (zooxanthellate) coral reefs is necessary for selecting and protecting unique areas of high living coral cover, diversity, and structural complexity that could aid in the recovery of the shallower fish and benthic communities.

In the past, an evaluation of deep-water fish habitats and abundance around Puerto Rico and the U.S. Virgin Islands, at depths ranging from about 100 - 450 m, was conducted using the Johnson-Sea-Link II submersible (Nelson and Appeldoorn, 1985). To this day, the upper insular slope reefs of Puerto Rico and the Virgin Islands, found at intermediate depths (30-100 m), remain largely undescribed.

The Seabed autonomous underwater vehicle (AUV) is a new imaging platform designed for high resolution optical and acoustic sensing (Singh et al., 2004). The Seabed was tested over the insular shelf slope off southwestern Puerto Rico in March 2002 to a maximum depth of $125 \mathrm{~m}$ (Armstrong et al., 2002; Singh et al., 2004). This test dive established the potential of this new tool for mapping and characterizing the upper insular slope coral reef habitat.

During June 2003, we used the Seabed for imaging the benthic habitats of the shelf edge and upper insular slope of the Hind Bank Marine Conservation District (MCD), south of St. Thomas, U.S. Virgin Islands. The MCD is a nonfishing area that was established as per recommendation of fishers, scientists and government officials in 1999, to conserve and manage representative samples of marine habitats and ecosystems and to maintain marine biodiversity. The area was originally managed as a seasonal closure for the protection of the red hind (Epinephelus guttatus) spawning aggregation on the eastern side of the MCD. The spawning aggregation primary site was described by Beets and Friedlander (1997). The dominant coral present was flattened colonies of Montastrea annularis. More recently, a limited number of diver surveys at depths of 38-39 m were conducted by Nemeth et al. (2004).

Up to now, very little quantitative information has been available on the structure and composition of the coral reefs at the MCD due to the depth of these reefs. The goal of this study was to characterize the benthic community structure and biodiversity of these deeper insular shelf corals reefs. The Seabed high resolution color images were used to describe the major components of the 
coral reef community of the MCD, which includes corals, gorgonians, sponges, other macro-invertebrates, and algae, and to quantify living coral cover, species richness, diversity, and evenness.

\section{Study area}

The Hind Bank MCD is located approximately $12 \mathrm{~km}$ south of St. Thomas, U.S. Virgin Islands at the shelf edge encompassing an area of approximately $41 \mathrm{~km}^{2}$ (Figure 1). According to the bathymetry map of this area, depth ranges within the MCD from about $30 \mathrm{~m}$ on the western part to more than $430 \mathrm{~m}$ off the shelf edge. Within the insular shelf area of the MCD the maximum depth is approximately $62 \mathrm{~m}$ with an average depth of $42 \mathrm{~m}$ on the eastern half. Four, one-kilometer long transects were selected for the AUV surveys based on the known distribution of coral reef habitats and fish spawning grounds provided by previous SCUBA assessments. The two transects on the western side of the MCD were parallel to shore over areas dominated by coral reefs. The eastern transects were oriented perpendicular to shore at known fish spawning sites.

\section{Materials and methods}

The Seabed AUV is composed of two torpedo-like body sections fixed to each other with vertical structural members (Figure 2). The AUV was designed to operate up to $2000 \mathrm{~m}$ depth to carry out photo transects, side-scan sonar and bathymetric surveys. A Pixelfly 1024 x 1280 pixel resolution CCD camera, with 12 bits of dynamic range, is the primary optical imaging sensor.

The camera was pointed straight down. A 150 watt-second strobe is used for photographic illumination. The strobe is mounted 1.4 meters aft of the camera to reduce the effects of lighting backscatter in the images (Figure 2a). The frequency of photos is a function of strobe recharge time (2.5 seconds). The size of the image was determined based on the altitude of the vehicle to the bottom and the field of view of the camera.

Measurements of velocity over the bottom, heading, altitude, pitch, roll, and integrated position are provided by a $300 \mathrm{kHz}$ Acoustic Doppler Current Profiler (ADCP), which projects four sonar beams into the water. These are arranged in a Janus configuration pointing $30^{\circ}$ fore, aft, to port and to starboard. We utilize the forward pointing beam for obstacle avoidance. A Paroscientific Model 8DP depth sensor provides depth information that, when combined with a dedicated vertical thruster, delivers depth accuracies in the order of $3.5 \mathrm{~cm}$ during our missions. More information on Seabed components, sensors, control systems, and navigation can be found in Singh et al. (2003).

The AUV, which runs at speeds between $0.3 \mathrm{~m} / \mathrm{s}$ to $1 \mathrm{~m} / \mathrm{s}$, was programmed to run at minimum speed and to maintain a fixed distance from the bottom to avoid collisions in case sudden changes in bottom relief were 
encountered. The distribution of the four thrusters, coupled with the passive stability of a two-hulled vehicle with a large meta-centric height (Figure 2b), allows the Seabed to survey close to the sea floor, even in very rugged terrain and to follow a greater than $45^{\circ}$ slope. As opposed to most other AUV's, the Seabed was designed to be hover capable, that is, to be able to independently drive in the $\mathrm{X}, \mathrm{Y}$ and $\mathrm{Z}$ axes.

Each transect was approximately $1 \mathrm{~km}$ in length and produced over 500 images, each about $3.1 \mathrm{~m}$ wide by $2.5 \mathrm{~m}$ long, at the predetermined $4 \mathrm{~m}$ distance from the bottom. The exact depth of each image was determined by combining the depth of the AUV (measured with the Paroscientific sensor) with its altitude (measured by the ADCP). The initial position of the vehicle at launch is determined by shipboard GPS with an accuracy of tens of meters.

Underwater imagery is typically characterized by low contrast and low color fidelity. The nonlinear attenuation of the visible spectrum in seawater causes parts of the visible spectrum to be preferentially attenuated. Thus most underwater images tend to be saturated in the blue-green region. We reprocessed the raw imagery to obtain three channel, 1280x1024x12bit RGB images. The 12 bits of dynamic range provided by the camera that is part of Seabed allow us to compensate and color balance the imagery as shown in Figure 3.

The enhanced benthic imagery was analyzed for percent cover of living corals and other benthic components using random points generated by the Point Count for Coral Reefs software (P. Dustan, personal communication). The clearest, best quality images (50-70 per transect) were selected and individually analyzed using 50 random points and the percent cover of corals, sponges, algae, and bare substrate was recorded. From images acquired within coral reef areas the diversity index for corals was calculated using the Shannon-Weaver Diversity index:

$$
\mathrm{H}^{\prime}=-\sum \mathrm{P}_{\mathrm{i}} \ln \mathrm{P}_{\mathrm{i}}
$$

where $\mathrm{P}_{\mathrm{i}}=\mathrm{n}_{\mathrm{i}} / \mathrm{n}$ and $\mathrm{n}=$ total number of coral colonies. Evenness was calculated using Pielou's evenness index:

$$
\mathrm{J}=\mathrm{H}^{\prime} / \ln \mathrm{H}_{\max }
$$

where $\mathrm{H}_{\max }=$ total number coral species.

\section{Results}

At the western side of the MCD, the reef at PR-03 had a depth range from 33 to $42 \mathrm{~m}$ (Figure 4a) while at PR-04, the reef extended from 36 to $41 \mathrm{~m}$ in depth (Figure $4 b$ ). Higher depths were found at the eastern side of the MCD 
where the transect lines were perpendicular to the coast and extended beyond the shelf edge. At PR-07 the reef was restricted to a narrow zone 45 to $47 \mathrm{~m}$ deep in a transect that exceeded $60 \mathrm{~m}$ in depth (Figure 4c). In a similar way, at PR-08 coral reefs were only present in the middle of the transect at depths from 41 to $46 \mathrm{~m}$ (Figure $4 \mathrm{~d}$ ). In all cases the AUV followed the bottom contour maintaining a distance of approximately $4 \mathrm{~m}$ from the bottom. In addition to depth, bottom composition varied considerably between the east and the west transects of the MCD. Transects PR-03 and PR-04 were mainly composed of coral reef areas (97 and 100\%, respectively), whereas transects PR-07 and PR08 consisted of small coral reef patches separated by hardground areas along with algal mats, sand, and sparse seagrasses (Figure 5). Hardgrounds are lowrelief areas where sediments have been lithified into rock. In these consolidated substrates sparse sponges, gorgonians and algae may be present. Algal mats are a dense layer of algae that blankets the bottom while "sand" refers to substrates of unconsolidated calcium carbonate grains. Seagrasses were only present within the algal mats and sand bottom categories. Within the reef areas, coral cover at PR-04 was significantly higher $(\mathrm{p}<0.05)$ than at the other three sites with coral cover ranging from 29 to $43 \%$ (Figure 6). Bare substrate was the second most important category, in terms of percent cover, within coral reefs areas, except for PR-03, where macroalgae was the dominant component. Macroalgae was characterized by green, brown, and red algae, while the bare substrate category includes dead coral colonies, uncolonized hard-bottom and sand.

Within the scleractinian cover composition, the image data analysis revealed dominance by Montastrea annularis complex at all transects, but particularly at PR-03 (Figure 7) where the average cover of M. annularis was about $90 \%$ and this dominance was nearly constant with depth. At PR-04 the reef was also highly dominated by the $M$. annularis complex but with increasing cover of the genus Agaricia with increasing depth (Figure 8). The $M$. annularis complex was less dominant at PR-07 (Figure 9) at around 50-63\% of the total coral cover. The least dominance of this species was found at $46 \mathrm{~m}$ in PR-08 where its coverage was reduced to less than $40 \%$ and the genus Agaricia covered up to $30 \%$ of the substrate (Figure 10). Overall, Montastrea annularis complex was the dominant coral species representing $92 \%$ of the coral cover. One-Way ANOVA showed statistical differences in coral cover among depths at PR-03 and PR-04 ( $p=0.0006$ and $p=0.005$, respectively), but no significant differences were found at PR-07 and PR-08 ( $p=0.138$ and $p=0.194$, respectively).

The relatively small Index of Diversity (range 1.48 to 1.85 , Table 1 ) further validates the dominance of the $M$. annularis complex over the rest of the species. Species richness was highest on the western side of the MCD with 14 identifiable coral species at PR-04 followed by 11 at PR-03. On the eastern side of the MCD, the coral reef at PR-07 and PR-08 consisted of only seven and nine coral species, respectively (Table 1 ). 
Within coral reef and hard ground areas, the benthic cover of other macro invertebrates was dominated by sponges and gorgonians at all sites (Table 2). The most dominant sponges were the giant barrel (Xestospongia muta) and rope sponges of the genus Aplysina. A total of 17 species of sponges, two hydrozoan corals (Millepora sp.), 10 gorgonians, one black coral (Cirrhipathes sp.), and four lobster and crab species (crustaceans) could also be identified in association with coral reef and hardground substrates. Most gorgonian species were found in the western part of the MCD at PR-03 and PR04. The only invertebrates associated with sand bottom and algae substrate that could be identified from the images were two species of conch (genus Strombus), three species of echinoderms, and the upside-down jellyfish Cassiopea. The echinoderms consisted of the sea urchin Meoma ventricosa and two species of sea cucumbers (holothurians). Seven algae and one seagrass species were identified in the phototransects (Table 3). Only functional groups could be reported for most algae except for Udotea cyathiformis and Halimeda sp. that could be distinguished due to their characteristic shape and were only found in the eastern side of the MCD. Turf algae are a multispecific assemblage of filamentous algae. The seagrass Halophila baillonis was found in sand bottoms and algal substrates at both PR-07 and PR-08.

\section{Discussion}

The geomorphology of the eastern side of the MCD, as depicted by the AUV transects, follows the description of Olsen and LaPlace (1978) who described the red hind spawning site with the bottom topography as a series of coral ridges, parallel to the 100 fathom $(182 \mathrm{~m})$ curve. These ridges were usually $100 \mathrm{~m}$ across and separated by calcareous sand which ranged from 50 to $300 \mathrm{~m}$ in width, with the dominant coral, Montastrea annularis, measuring less than $1 \mathrm{~m}$ in diameter. From a series of SCUBA dives at the red hind spawning site along the shelf edge reef, at depths of 38-48 m, Clavijo and Tobias (1985) described the substrate as dominated by dense scleractinian cover, primarily plates of Montastrea annularis. Nemeth (2003) reported Montastrea franksi as the dominant species in the MCD and within the spawning aggregation site.

The Montastrea annularis species complex is composed of the sibling species M. annularis, M. faveolata, and M. franksi (Weil and Knowlton, 1994), which are the dominant reef building corals in the tropical Western Atlantic (Goreau, 1959). While the M. annularis complex represented $20 \%$ to $60 \%$ of the corals found in near shore and mid-shelf reef areas in depths of 5 to $25 \mathrm{~m}$ (Herzlieb et al., in press), it dominated in 30 to $40 \mathrm{~m}$ depths with cover ranging from 60 to nearly $100 \%$. In areas deeper than $40 \mathrm{~m}$ it still represented 50 to $60 \%$ of the coral cover. Also common in deep reef areas of the Caribbean are several species of the genus Agaricia (Lang, 1974; Reed, 1985; Liddell and Ohlhorst, 1988). Within the MCD, Agaricia sp. represented up to $10 \%$ of the coral cover at depths less than $41 \mathrm{~m}$ and over $20 \%$ of the cover in depths greater than $45 \mathrm{~m}$. 
The M. annularis complex and Agaricia sp. both grew as plate-like formations. The plate-like morphology is an adaptation to reduced sunlight at deeper depths (Grauss and Macintyre, 1982). Porites astreoides and Mycetophyllia sp. were found at all depths between $33 \mathrm{~m}$ and $47 \mathrm{~m}$. Agaricia $s p$. was only found in small colonies that were easily identified by their spiraling ridge pattern and brownish color. The average living coral cover seen in the photo transects was $43 \%$ with maximum cover of $70 \%$ found in some areas at $40 \mathrm{~m}$. Also found in abundance was an encrusting sponge, which is most likely Cliona sp. This sponge accounted for $96 \%$ of all the sponges found, while most of the other sponges present were columnar. Cliona is a brown-black sponge that grows over corals as it dissolves them, which may account for the high percentage of bare substrate.

In Bermuda, most deep-water hermatypic corals grow on reef substrate down to $60 \mathrm{~m}$ (Fricke and Meischner, 1985). The coral growth in the deeper reef areas in Bermuda appeared to be controlled by macroalgae growth. In the Bahamas, coral assemblages less than $30 \mathrm{~m}$ depth represented 3 to $25 \%$ of benthic cover and were dominated by Agaricia agaricites, M. cavernosa, M. annularis, $P$. astreoides, and $P$. porites (Liddell et al., 1997). The deeper (30-50 m) coral assemblages represented less than $3 \%$ of the benthic cover and were dominated by M. cavernosa and Agaricia spp. (Liddell et al., 1997). Low water temperatures favor macroalgae growth leading to a reduction of coral growth (Johannes et al., 1983). In the fore-reef slope of Jamaica, the flattened growth form of M. annularis is the dominant species of coral above $45 \mathrm{~m}$ (Goreau and Land, 1974).

At a study site close to the PR-07 transect in this study, Nemeth et al. (2004) reported mean values of $28 \%$ living corals, $35 \%$ macroalgae, $20 \%$ dead coral with turf algae, $7 \%$ sand/sediment, $4 \%$ sponges, and $0 \%$ gorgonians. This compares favorably with the AUV estimates of living coral (29\%) and sponges $(3.8 \%)$ at PR-07. The bare substrate category was $28.5 \%$, coralline algae (16.6\%), macroalgae $(21.2 \%)$, and gorgonians $(1 \%)$. In a separate study, Herzlieb et al. (in press) found coral cover on the western end of the MCD to be $44.8 \%$ with coral cover of the M. annularis complex near $80 \%$. Nemeth et al. (2004) also reported dominance by the M. annularis complex at $76 \%$ of total living coral cover, a 1.4 diversity index, coral bleaching at $6.5 \%$ and incidence of diseased corals at $1.4 \%$. The present study could not detect any evidence of coral disease in any of the photo transects and at PR-07, the diversity index was 1.8 with dominance of M. annularis complex at 50-60\%. The reefs at PR-07 are substantially deeper $(45-47 \mathrm{~m})$ than the reef area described by Nemeth et al. (2004) at 38-39 m. This could account for the observed differences in some of these coral reef parameters.

Although the coral reefs of the MCD are largely unknown, they appear to be relatively undisturbed by anthropogenic factors due to the considerable distance to land sources of runoff and pollution (Herzlieb et al., in press). Their 
greater depth also protects them from wave damage from storm surge. Intermediate depth coral reefs, such as those of the MCD, could serve as refugia for shallow water species in times of environmental stress (sensu Riegl and Piller, 2003).

The high coral cover throughout the MCD suggests that these reefs are largely unaffected by natural and human disturbances. Since the late 1970's, hurricanes (Woodley et al., 1981; Edmunds and Witman, 1991) and disease (Gladfelter, 1982) have devastated shallow water reef communities throughout the Caribbean. Edmunds and Witman (1991) reported that Hurricane Hugo destroyed over $33 \%$ of the live cover of $M$. annularis on shallow $(10 \mathrm{~m})$ reefs off St. John, US Virgin Islands. Although the turbulence from large hurricane waves can cause fragmentation and abrasion damage in many shelf edge reefs, these effects are limited to depths of $30 \mathrm{~m}$ (Blanchon and Jones, 1997). The relatively high depths present at the MCD protects these coral reefs from the high turbulence generated by hurricane waves, since the minimum depth of the surveyed reefs was $33 \mathrm{~m}$ and most reefs were present at depths of $40 \mathrm{~m}$ or more. Recently, the mortality rate of shallow water corals in the Caribbean has increased dramatically due to a variety of diseases (Richardson et al., 1998a,b; Harvell et al., 1999). Although no disease was evident in the Seabed AUV digital imagery, Nemeth et al. (2004) reported that low levels of disease occurred within the MCD in spring 2003, but higher levels of disease (over $10 \%$ ) occurred on similar deep reefs outside the MCD. They speculated that the unprotected deep reefs may have higher incidence of disease due to commercial fish traps, which not only injure corals but may act as vectors of disease when fishermen transfer traps from shallow to deep reefs.

There are numerous reports in the literature describing intermediate depth coral reefs $(30-50 \mathrm{~m})$ present in the deep fore-reef and upper insular slopes of many Caribbean Islands. However, the coral reefs of the MCD described here are present within the deeper zones of the insular shelf, a unique habitat that has not been described elsewhere. The distribution and characterization of similar habitats at other locations needs to be established before meaningful comparisons with similar coral communities can be made.

In summary, the quantitative characterization of benthic communities associated with the deep coral reef habitats of the MCD, as provided by the four AUV phototransects, compares favorably with the available information from previous diving surveys in this area. In most cases, the resolution of the Seabed digital imagery was adequate to identify the organisms to the species level. In other cases, only genera could be identified, and for most of the algae, only major groups could be identified. This study demonstrates that the high quality digital imagery provided by the Seabed AUV can be used to characterize the deeper zooxanthellate coral reef habitat present at depths greater than $30 \mathrm{~m}$, which for most areas of the world, remain largely unknown. Quantitative 
determinations of sessile-benthic populations, as well as the presence of motilemegabenthic invertebrates and algae were obtained.

Our initial results show that the deeper reefs of the MCD are largely unaffected by hurricane disturbances, human impacts, and disease. Therefore, they could serve as a potential refuge areas and a source of larvae for the recovery of shallower coral reef communities present downstream and may play a critical role in the reestablishment of fish populations in adjacent insular shelf areas.

\section{Acknowledgments:}

We thank Captain Harry Montalvo and the crew of the $R / V$ Chapman and the field and technical assistance of members of the Seabed AUV operations team. We appreciate the recommendations for transect locations provided by Elizabeth Whiteman, the field assistance by Stacy Albritton, Elizabeth Kadison, Yasmín Detrés, Fernando Gilbes, Liane Guild, and Jeannette Arce, and the helpful comments and corrections of two anonymous reviewers. Funding was provided in part by the CenSSIS ERC of the National Science Foundation under grant EEC-9986821 and by the Caribbean Fishery Management Council. University of the Virgin Islands staff time was supported by a grant from Sea Grant (R-101-1-02) to R. Nemeth.

\section{References:}

Armstrong, R.A., Singh, H., Torres, J., 2002. Benthic survey of insular slope coral reefs using the Seabed AUV. Backscatter 13 (3), 22-25.

Beets, J., Friedlander, A., 1997. Evaluation of the spawning aggregation closure for red hind (Epinephelus guttatus), St. Thomas, US Virgin Islands. Report to the Caribbean Fishery Management Council, San Juan, Puerto Rico, 17 pp.

Blanchon, P., Jones, B., 1997. Hurricane control on shelf-edge reef architecture around Grand Cayman. Sedimentology 44, 479-506.

Clavijo, I.E., Tobias, W.J., 1985. Virgin Islands commercial fisheries research and development project (PL 88-309) Project No. 2-411-R1. Annual Report, April 1, 1984 to March 31, 1985, National Marine Fisheries Service, St. Petersburg, Florida, 22 pp.

Edmunds, P.J., Witman, J.D., 1991. Effects of Hurricane Hugo on the primary framework of a reef along the south shore of St. John, US Virgin Islands. Marine Ecology Progress Series 78, 201-204. 
Fricke, H., Meischner, D., 1985. Depth limits of Bermudan scleractinian corals: A submersible survey. Marine Biology 88 (2), 175-187.

Gardner, T.A., Cote, I.M., Gill, J.A., Grant, A., Watkinson, A.R., 2003. Long term region-wide declines in Caribbean corals. Science 301, 958-960.

Gladfelter, W.G., 1982. White-band disease in Acropora palmata: implications for the structure and growth of shallow reefs. Bulletin of Marine Science 32, 639-643.

Goreau, T.F., 1959. The ecology of Jamaican reefs. I. Species composition and zonation. Ecology 40, 67-90.

Goreau, T.F. Land, L.S. 1974. Fore-reef morphology and depositional processes, North Jamaica. In: Laporte, L.F. (Ed.), Reefs in Time and Space. Society of Economic Paleontologists and Mineralogists Special Publication No. 8, Tulsa, Oklahoma, pp. 77-89.

Grauss, R.R, Macintyre, I.E., 1982. Variation in growth forms of the reef coral Montastrea annularis: a quantitative evaluation of growth response to light distribution using computer simulation. In: Rutzler, K., Macintyre, I.G. (Eds.), The Atlantic Barrier Reef Ecosystem at Carrie Bow Cay, Belize I. Structure and Communities. Smithsonian Contributions in Marine Science 12. Smithsonian Institution Press, Washington, D.C., pp. 441-464.

Harvell C.D., Kim, K., Burkholder, J.M., Colwell, R.R., Epstein, P.R., Grimes, D.J., Hofmann, E.E., Lipp, E.K., Osterhaus, A.D.M.E., Overstreet, R.M., Porter, J.W., Smith, G.W., Vasta, G.R., 1999. Emerging marine diseases-climate links and anthropogenic factors. Science 285, 1505-1510.

Herzlieb, S., Kadison, E., Blondeau, J., Nemeth, R.S., in press. Comparative assessment of coral reef systems located along the insular platform of St. Thomas, US Virgin Islands and the relative effects of natural and human impacts. Proc. 10th Int. Coral Reef Symp. Okinawa, Japan.

Johannes, R.E., Wiebe, W.J., Crossland, C.J., Rimmer, D.W., Smith, S.W., 1983. On the latitudinal limits of coral reef growth. Marine Ecology Progress Series 11, 105-111.

Lang, J.C., 1974. Biological zonation at the base of a reef. American Scientist 62, 272-281. 
Liddell, W.D., Ohlhorst, S.L., 1988. Hard substrata community patterns, 1-120m., North Jamaica. Palaios 3, 413-423.

Liddell, W. D., Avery, W.E., Ohlhorst, S.L., 1997. Patterns of benthic community structure, $10-250 \mathrm{~m}$, the Bahamas. Proc. 8th Int. Coral Reef Symp. Panama,1: 437-442.

Nelson, W. R., Appeldoorn, R.S., 1985. A submersible survey of the continental slope of Puerto Rico and the U.S. Virgin Islands, October 1-23, 1985. Cruise report, $R / V$ Seward Johnson, National Marine Fisheries Service, Pascagoula, Mississippi Laboratories, 76 pp.

Nemeth, R.S., 2003. Investigating movement patterns and spawning habitat of red hind grouper in a newly established marine fishery reserve in the U.S. Virgin Islands. Final project report for MARFIN (award NA97FF0348), National Marine Fisheries Service, 21 pp.

Nemeth, R.S., Herzlieb, S., Kadison, E.S., Taylor, M., Rothenberger, P., Harold, S., Toller, W., 2004. Coral reef monitoring in St. Croix and St. Thomas, United States Virgin Islands. Final report submitted to Department of Planning and Natural Resources, U.S. Virgin Islands, $79 \mathrm{pp}$.

Olsen, D.A., LaPlace, J.A., 1978. A study of the Virgin Island grouper fishery based on a breeding aggregation. Proc. Gulf and Carib. Fish. Inst. 31, 130-144.

Reed, J.K., 1985. Deepest distribution of Atlantic hermatypic corals discovered in the Bahamas. Proc. 5th Int. Coral Reef Congress, Tahiti, 6, 249-254.

Richardson, L.L., Goldberg, W.M., Carlton, R.G., Halas, J.C., 1998a. Coral disease outbreak in the Florida Keys: Plague Type II. Revista de Biología Tropical 46 Supl.5, 187-198.

Richardson, L.L., Goldberg, W.M., Kuta, K.G., Aronson, R.B., Smith, G.W., Ritchie, K.B., Halas, J.C., Feingold, J.S., Miller, S., 1998b. Florida's mystery coral killer identified. Nature 392, 557-558.

Riegl, B., Piller, W.E., 2003. Possible refugia for reefs in times of environmental stress. International Journal of Earth Science 92, 520531.

Singh, H., Armstrong, R.A., Gilbes, F., Eustice, R., Roman, C., Pizarro, O., Torres, J., 2004. Imaging coral I: Imaging coral habitats with the Seabed AUV. Subsurface Sensing Technologies and Applications 5 (1), 25-42. 
Weil, E., Knowlton, N., 1994. A multi-character analysis of the Caribbean coral Montastrea annularis (Ellis and Solander, 1786) and its two sibling species, M. faveolata (Ellis and Solander, 1786) and $M$. franksi (Gregory, 1895). Bulletin of Marine Science 55, 151-175.

Woodley, J.D., Chornesky, E.A., Clifford, P.A., Jackson, J.B.C., Kaufman, L.S., Knowlton, N., Lang, J.C., Pearson, M.P., Porter, J.W., Rooney, M.C., Rylaarsdam, K.W., Tunnicliffe, V.J., Wahle, C.M., Wulff, J.L., Curtis, A.S.G., Dallmeyer, M.D., Jupp, B.P., Koehl, M.A.R., Neigel, J., Sides, E.M., 1981. Hurricane Allen's impact on Jamaican coral reefs. Science 214, 749-755. 


\section{Figure Captions:}

1. Map of the Hind Bank MCD. The location of the MCD in relation to Puerto Rico and the U.S. Virgin Islands is indicated by an arrow. Corner coordinates are (A) $18^{\circ} 13.2^{\prime} \mathrm{N}, 65^{\circ} 06^{\prime} \mathrm{W}$; (B) $18^{\circ} 13.2^{\prime} \mathrm{N}, 64^{\circ} 59^{\prime} \mathrm{W}$; (C) $18^{\circ} 10.7^{\prime} \mathrm{N}, 65^{\circ} 06^{\prime} \mathrm{W}$; (D) $18^{\circ} 11.8^{\prime} \mathrm{N}, 64^{\circ} 59^{\prime} \mathrm{W}$. (Federal Register 64 (213): 60132-60133; November 4, 1999) (50 CFR Part $622 \S 622.33$ (b) (1)).

2. The Seabed AUV: (A) schematic diagram of the major components, and (B) external view.

3. The reef at a depth of $40 \mathrm{~m}$ at PR-04 before (A) and after (B) color enhancement. Scale bar $=1 \mathrm{~m}$.

4. a-d. Depth profiles of the AUV transects: (a) PR-03, (b) PR-04, (c) PR-07, and (d) PR-08. The box in (c) and (d) indicate where the coral reef was located within the transect. The reef was continuous over the entire transect in (a) and (b).

5. Percent distribution of various bottom types along the four transects

6. Bottom composition within the coral reef areas of each transect. Bare substrate category includes dead coral colonies, uncolonized hard-bottom and sand.

7. Coral cover by species and depth at PR-03.

8. Coral cover by species and depth at PR-04.

9. Coral cover by species and depth at PR-07.

10. Coral cover by species and depth at PR-08. 


\begin{tabular}{|c|c|c|c|}
\hline & & & \\
Transect & Species Richness & Diversity Index (H') & Evenness (J) \\
\hline PR-03 & 11 & 1.48 & 0.615 \\
\hline PR-04 & 14 & 1.73 & 0.655 \\
\hline PR-07 & 7 & 1.85 & 0.949 \\
\hline PR-08 & 9 & 1.50 & 0.684 \\
\hline
\end{tabular}

Table 1: Species richness, diversity and evenness at the four transects. 


\begin{tabular}{|c|c|c|c|c|c|c|c|c|c|c|c|}
\hline \multirow[b]{2}{*}{ Group/Scientific Name } & \multicolumn{2}{|c|}{ PR 03} & \multirow{2}{*}{$\begin{array}{c}\text { PR 04 } \\
\text { CR } \\
\end{array}$} & \multicolumn{4}{|c|}{ PR 07} & \multicolumn{4}{|c|}{ PR 08} \\
\hline & CR & HG & & $\mathbf{C R}$ & HG & AM & SA & $\mathbf{C R}$ & HG & AM & $\overline{\text { SA }}$ \\
\hline \multicolumn{12}{|l|}{ PORIFERA } \\
\hline Cliona sp. & + & + & + & + & & & & & & & \\
\hline Aplysina cauliformis & & & + & & & & & + & & & \\
\hline Aplysina archeri & + & & & & & & & & & & \\
\hline Aplysina sp. & + & + & + & + & + & & & + & + & & \\
\hline Chondrilla nucula & & + & & & & & & & & & \\
\hline Diplastrella sp. & & + & + & + & + & & & + & & & \\
\hline Agelas clathrodes & + & + & + & + & + & & & + & + & & \\
\hline Agelas conifera & & + & + & + & + & & & + & + & & \\
\hline Geodia neptuni & & + & + & + & + & & & + & + & & \\
\hline Amphimedon compressa & + & & & + & + & & & + & + & & \\
\hline Pseudoceratina crassa & & & + & & & & & + & + & & \\
\hline Mycale laevis & & & + & & & & & + & & & \\
\hline Xestospongia muta & & & + & + & + & & & + & + & & \\
\hline Neofibularia nolitangere & & & & + & & & & & & & \\
\hline Cinachyra sp. & & & & & & & & & + & & \\
\hline Cribochalina vasculum & & & & & & & & + & + & & \\
\hline Strongylacidon sp. & & & & & & & & + & & & \\
\hline \multicolumn{12}{|l|}{ CNIDARIA } \\
\hline \multicolumn{12}{|l|}{ Hydrozoans } \\
\hline Millepora squarrosa & & + & & & & & & & & & \\
\hline Millepora alcicornis & & & + & & & & & + & + & & \\
\hline \multicolumn{12}{|l|}{ Scyphozoa } \\
\hline Cassiopea sp. & & & & & & & + & & & & \\
\hline \multicolumn{12}{|l|}{ Gorgonacea } \\
\hline Plexaura sp. & & + & + & & & & & & & & \\
\hline Ellisella barbadensis & + & & & & + & & & + & & & \\
\hline Pseudopterogorgia sp. & + & & + & & + & & & & & & \\
\hline Plexaurella nutans & + & & + & & & & & & + & & \\
\hline Plexaurella sp. & + & & + & & & & & & + & & \\
\hline Gorgonia sp. & + & & + & + & & & & & & & \\
\hline Eunicea sp. & + & & + & & + & & & & & & \\
\hline Leptogorgia hebes & + & & & + & & & & & & & \\
\hline Pseudoplexaura sp. & & & + & + & & & & & & & \\
\hline Muriceopsis sp. & & & & & & & & & + & & \\
\hline \multicolumn{12}{|l|}{ Antipatharia } \\
\hline Cirrhipathes sp. & & & + & & & & & + & + & & \\
\hline \multicolumn{12}{|l|}{ ECHINODERMATA } \\
\hline Eostichopus sp. & & & & & & & + & & + & & \\
\hline Holothuria sp. & & & & & & & + & & & & \\
\hline Meoma ventricosa & & & & & & & & & & & + \\
\hline \multicolumn{12}{|l|}{ ARTHROPODA } \\
\hline Scyllarides aequinoctialis & & & & & + & & & & & & \\
\hline Panulirus argus & & & & & + & & & & + & & \\
\hline Palinurellus guandlachi & + & & & & & & & & & & \\
\hline Mithrax sp. & & & + & & & & & + & & & \\
\hline \multicolumn{12}{|l|}{ MOLLUSCA } \\
\hline Strombus gigas & & & & & & & + & & & & + \\
\hline Strombus costatus & & & & & & & & & & & + \\
\hline
\end{tabular}

Table 2: Macro invertebrates (other than Scleractinians) identified in the phototransects $(\mathrm{CR}=$ Coral Reef, $\mathrm{HG}=$ Hardground, $\mathrm{AM}=$ Algal Mat, $\mathrm{SA}=$ Sand Bottom + Algae $)$. 


\begin{tabular}{|c|c|c|c|c|c|c|c|c|c|c|c|}
\hline & \multicolumn{2}{|c|}{ PR 03 } & PR 04 & \multicolumn{4}{|c|}{ PR 07 } & \multicolumn{4}{|c|}{ PR 08 } \\
\hline Group/Scientific Name & $\mathbf{C R}$ & HG & CR & CR & HG & $\mathbf{A M}$ & SA & $\mathbf{C R}$ & HG & $\mathbf{A M}$ & SA \\
\hline CYANOBACTERIA & & & & & + & + & & & & & \\
\hline \multicolumn{12}{|l|}{ ALGAE } \\
\hline Brown algae & + & + & + & + & + & + & & + & + & + & \\
\hline Red algae & & & & & & + & & + & & + & \\
\hline Red coralline algae & + & + & + & + & + & & & + & + & & \\
\hline Green algae & & & + & + & + & & & & & & \\
\hline Udotea cyathiformis & & & & & & + & + & & + & + & + \\
\hline Halimeda sp. & & & & & + & + & + & + & + & & \\
\hline Turf algae & + & + & + & + & + & & & + & + & & \\
\hline \multicolumn{12}{|l|}{ ANGIOSPERMAE } \\
\hline Halophila baillonis & & & & & & + & + & & & + & + \\
\hline
\end{tabular}

Table 3: Plants identified in the phototransects $(\mathrm{CR}=$ Coral Reef, $\mathrm{HG}=$ Hardground, $\mathrm{AM}=\mathrm{Algal}$ Mat, $\mathrm{SA}=$ Sand Bottom + Algae). 
Revised Figures

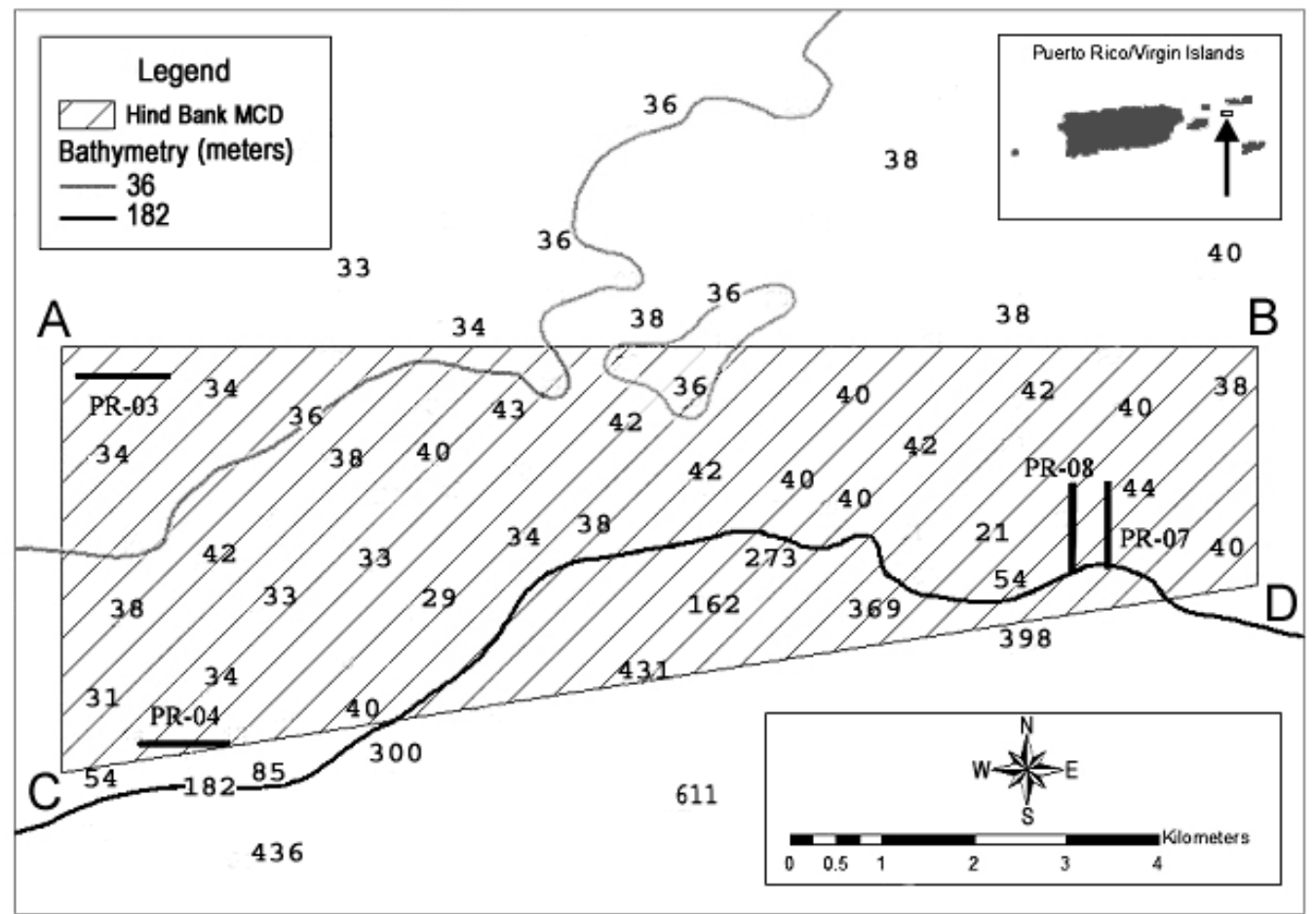

Figure 1 


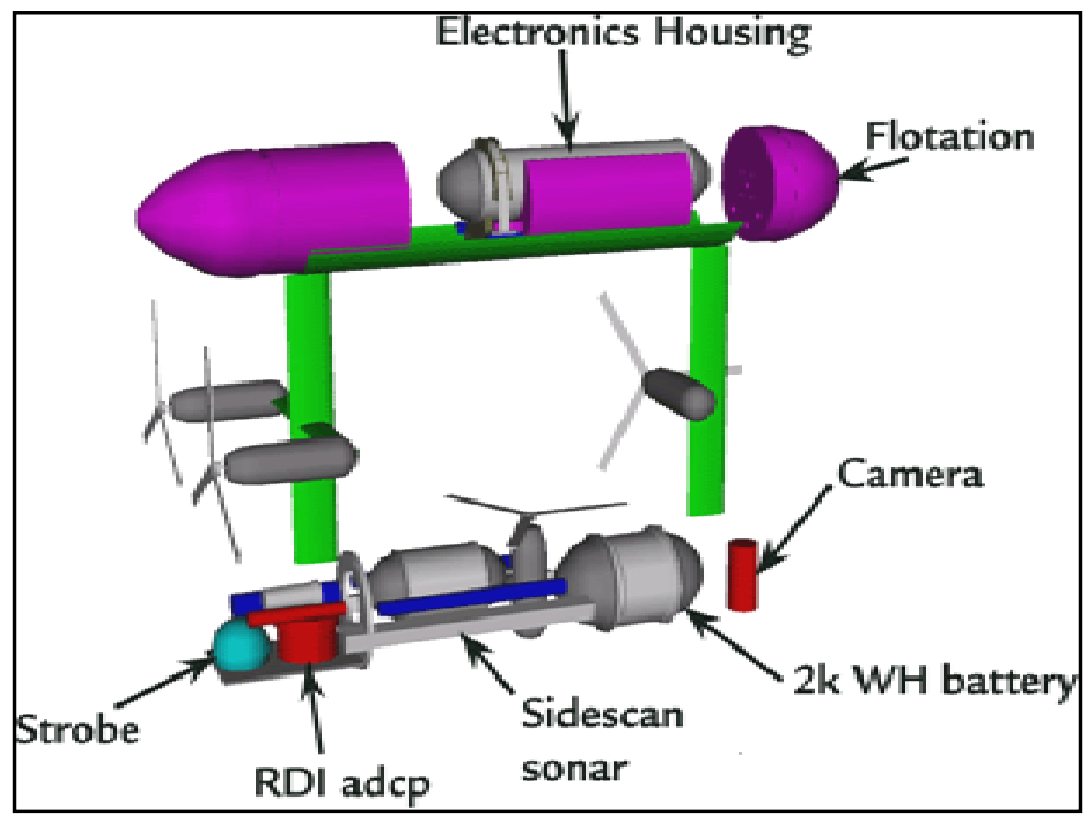

A

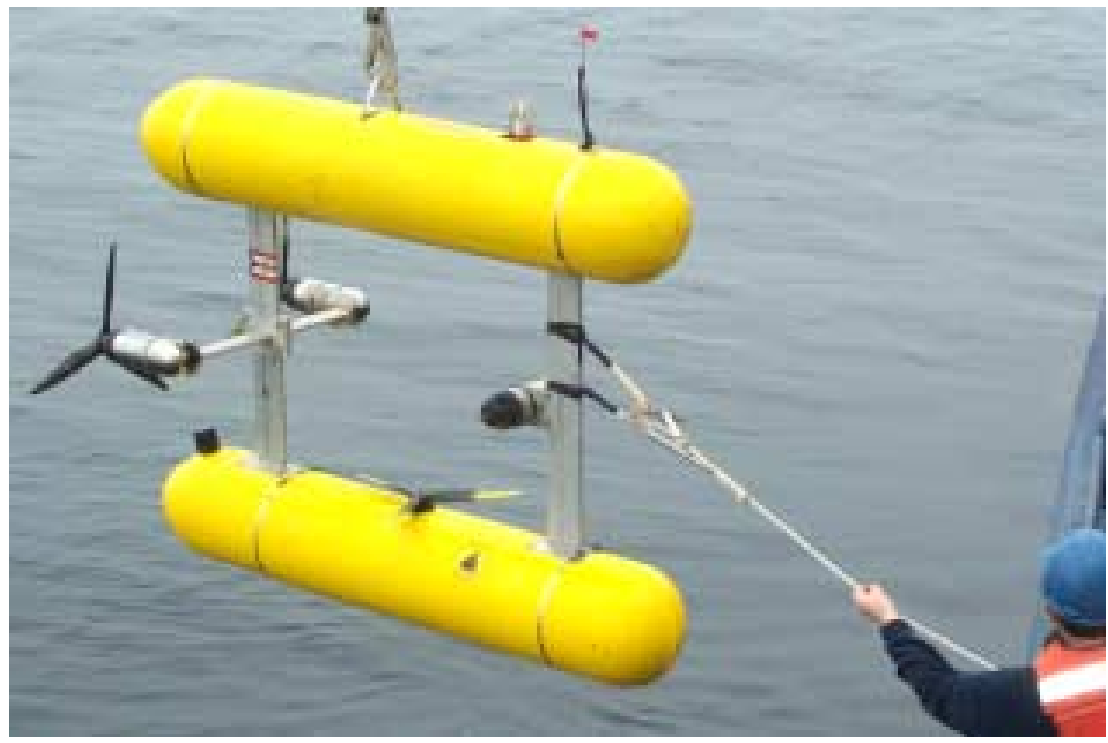

B

Figure 2 


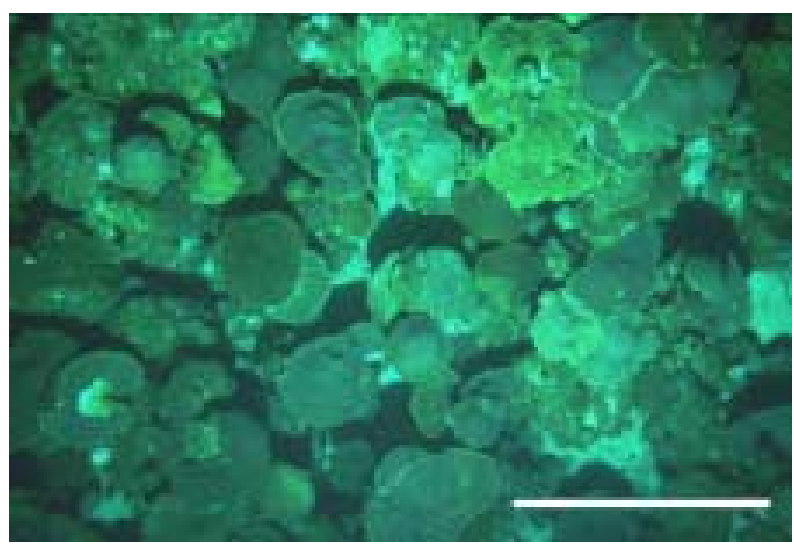

A

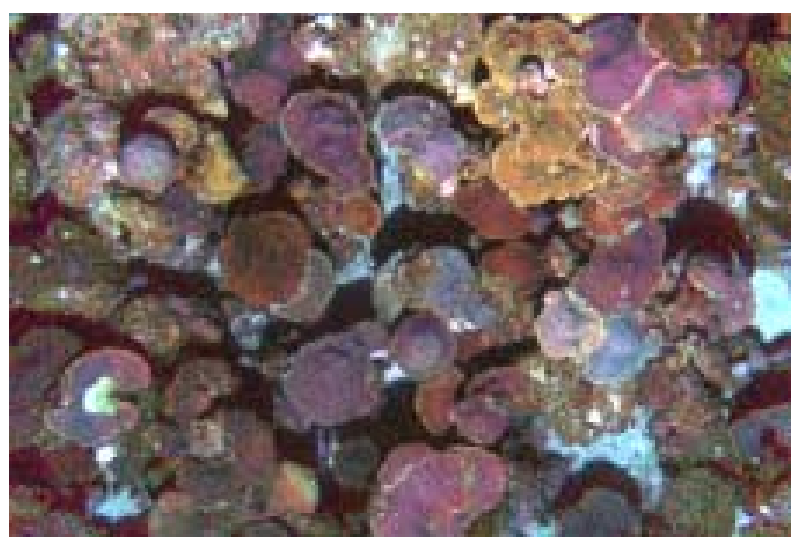

B

Figure 3 


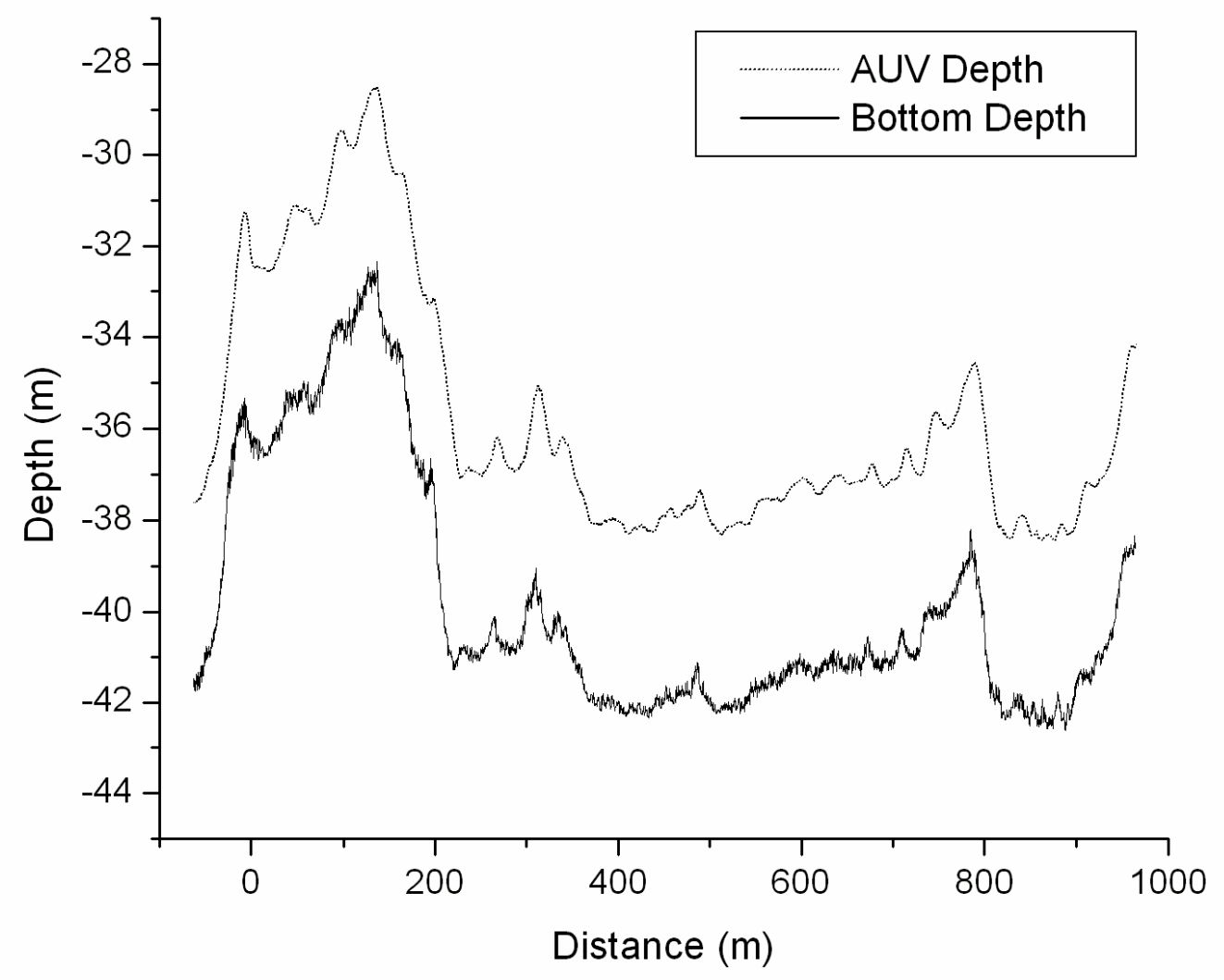

Figure $4 \mathrm{a}$ 


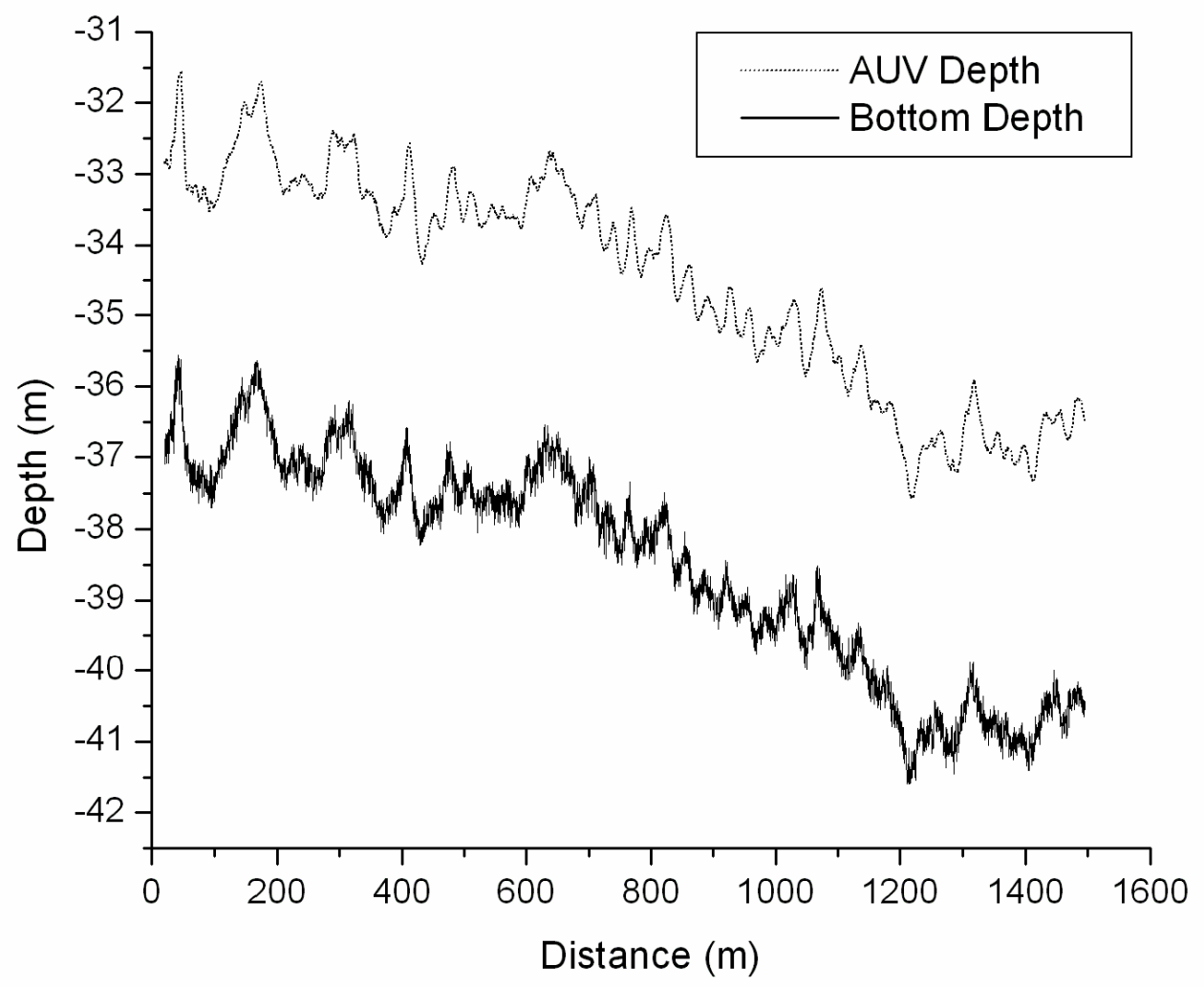

Figure $4 b$ 


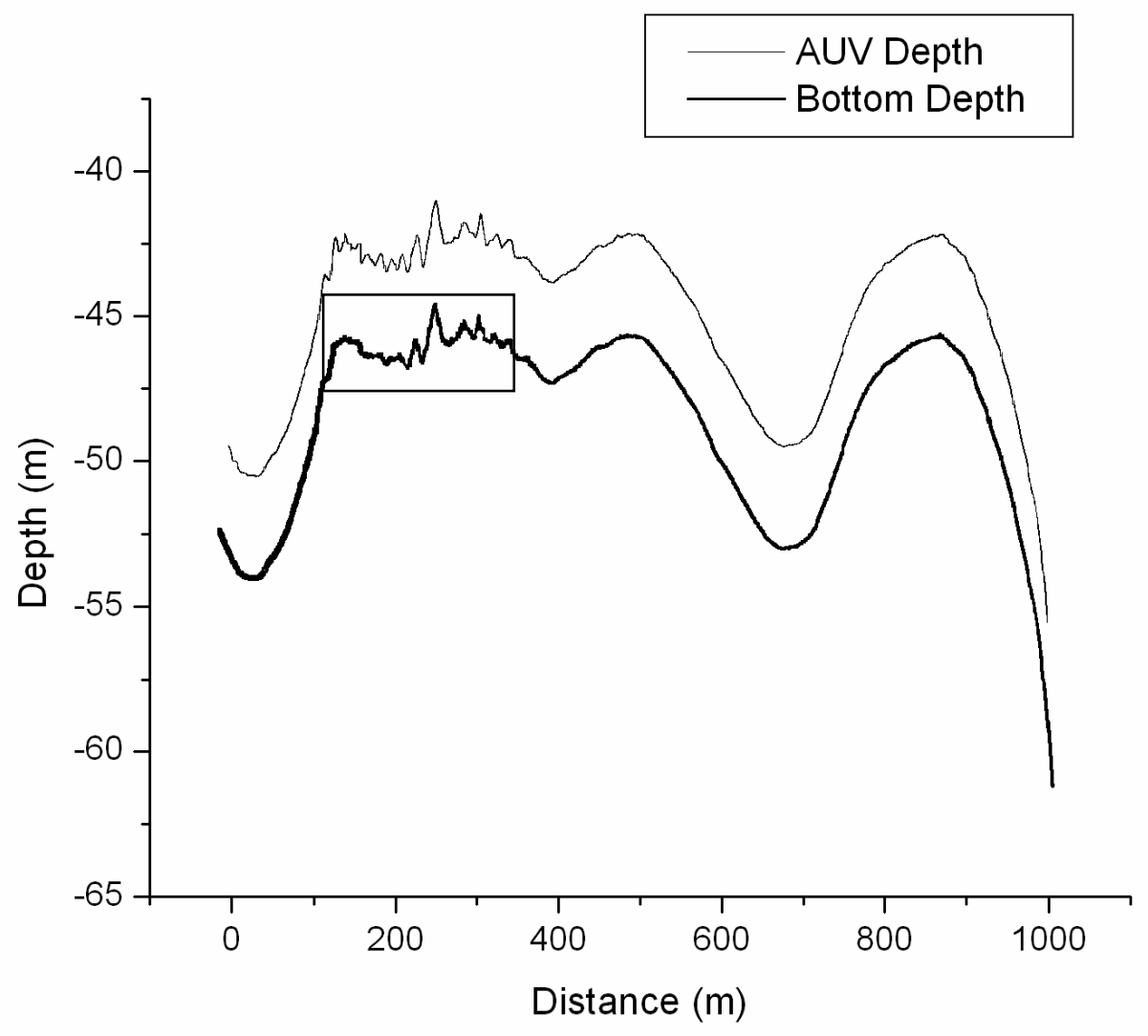

Figure 4c 


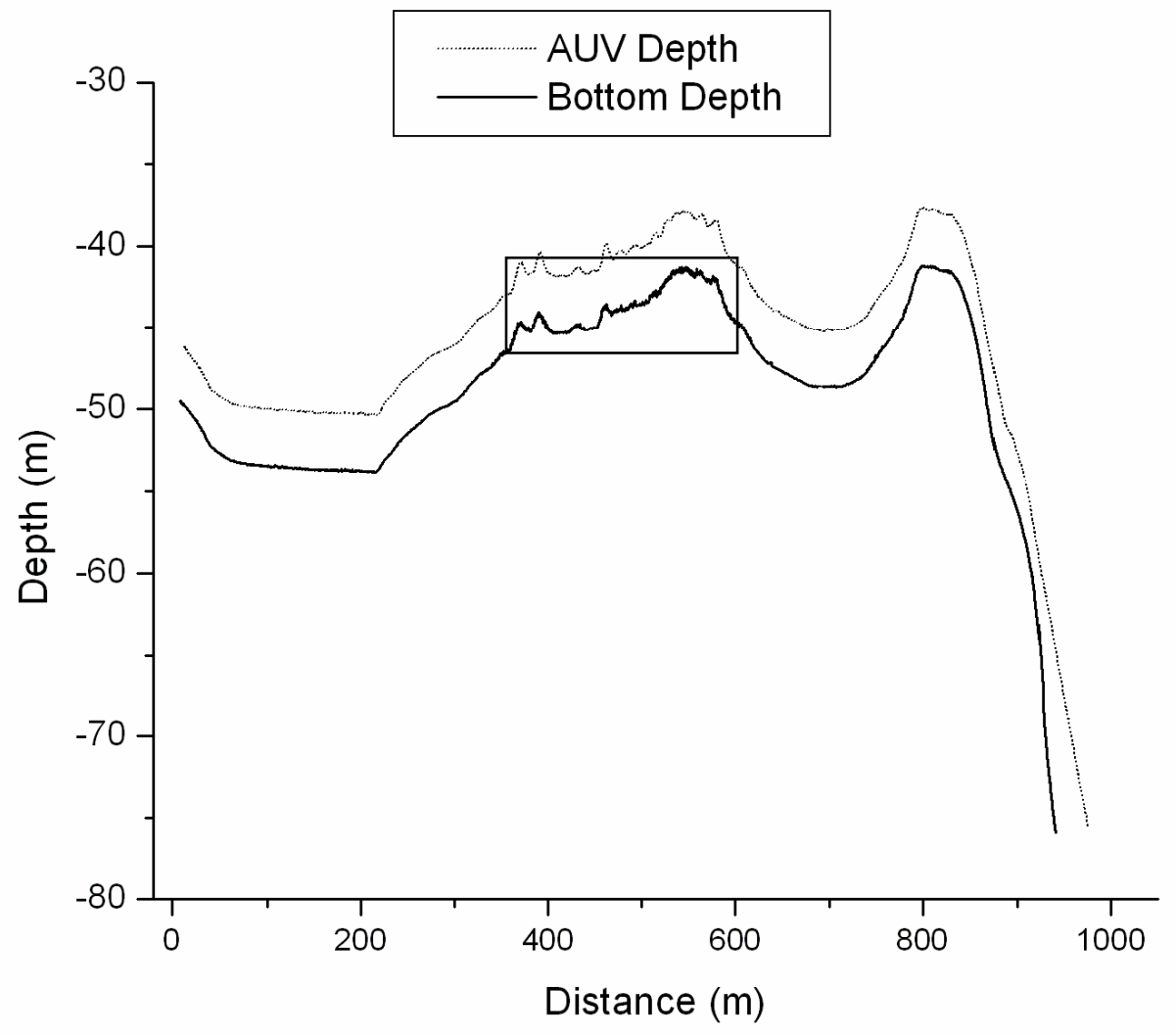

Figure $4 d$ 


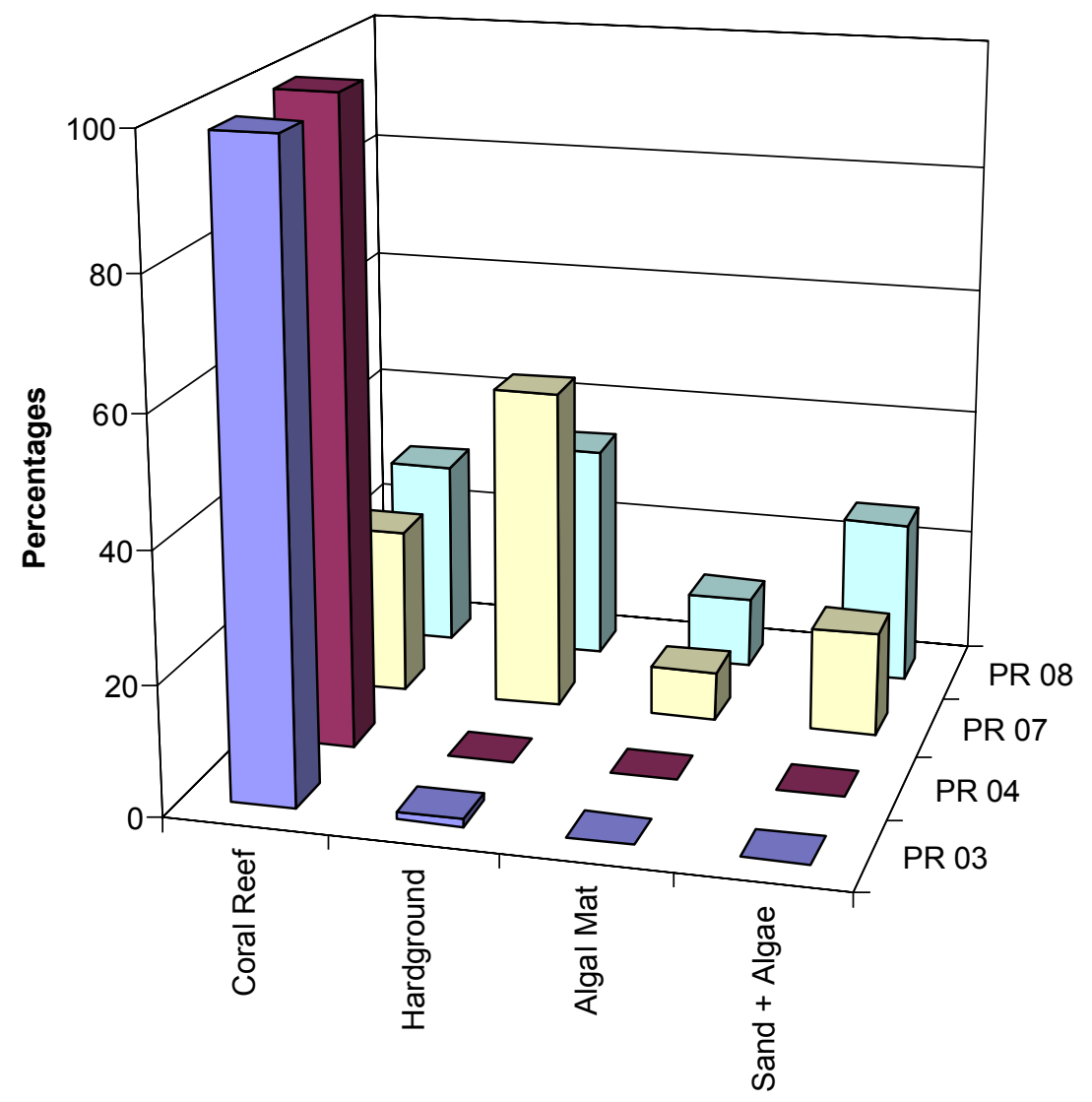

Figure 5. 


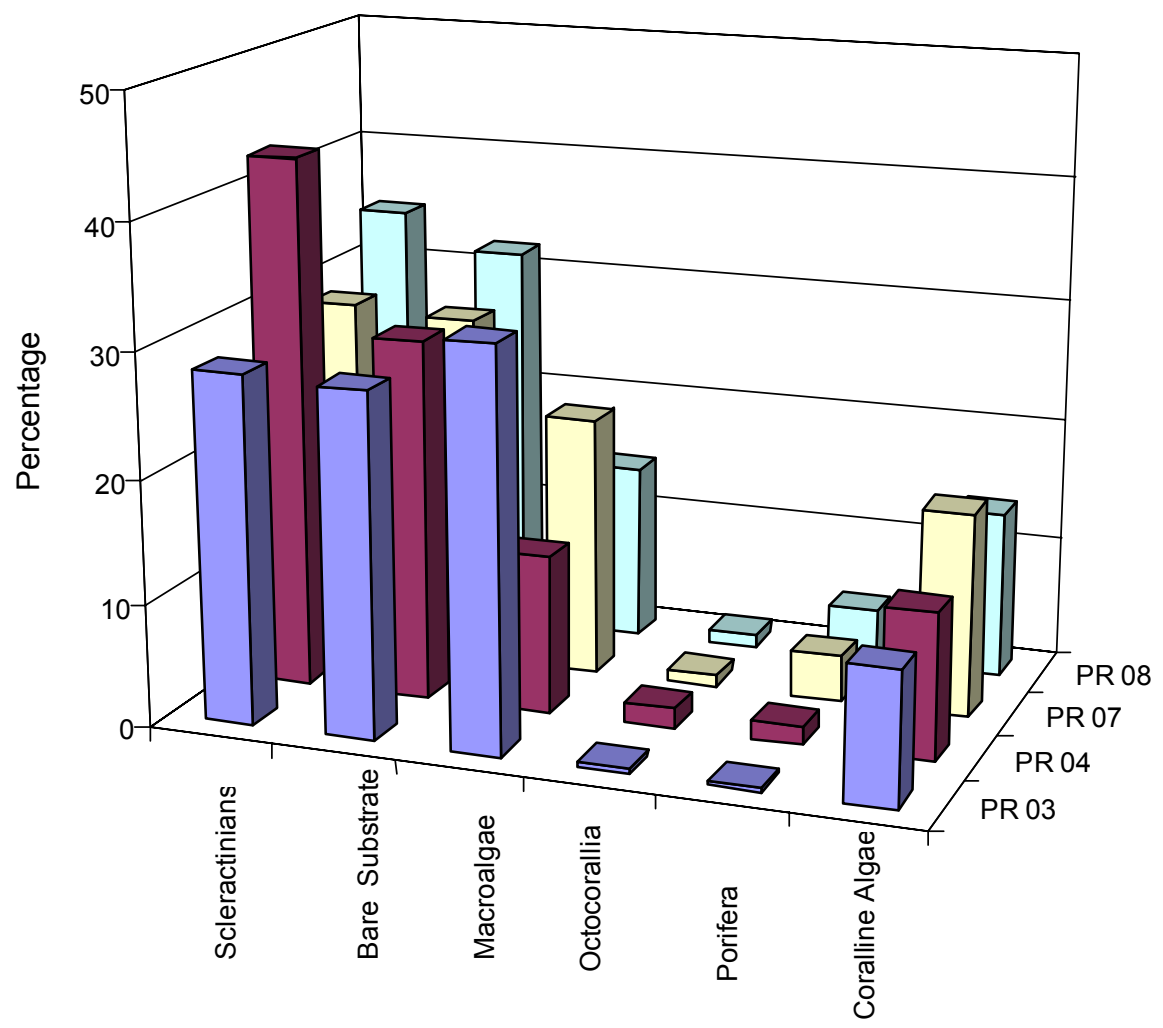

Figure 6. 


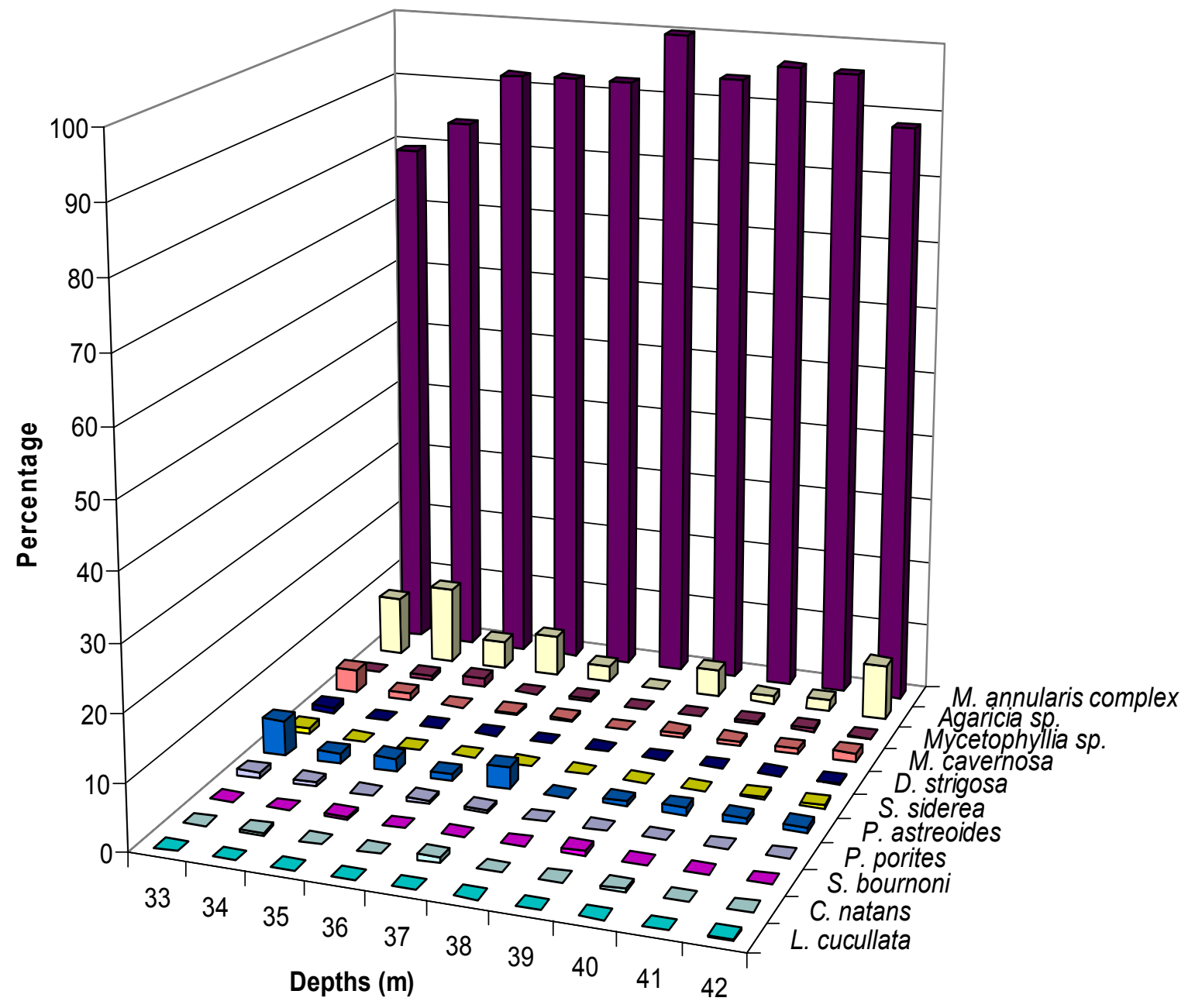

Figure 7. 


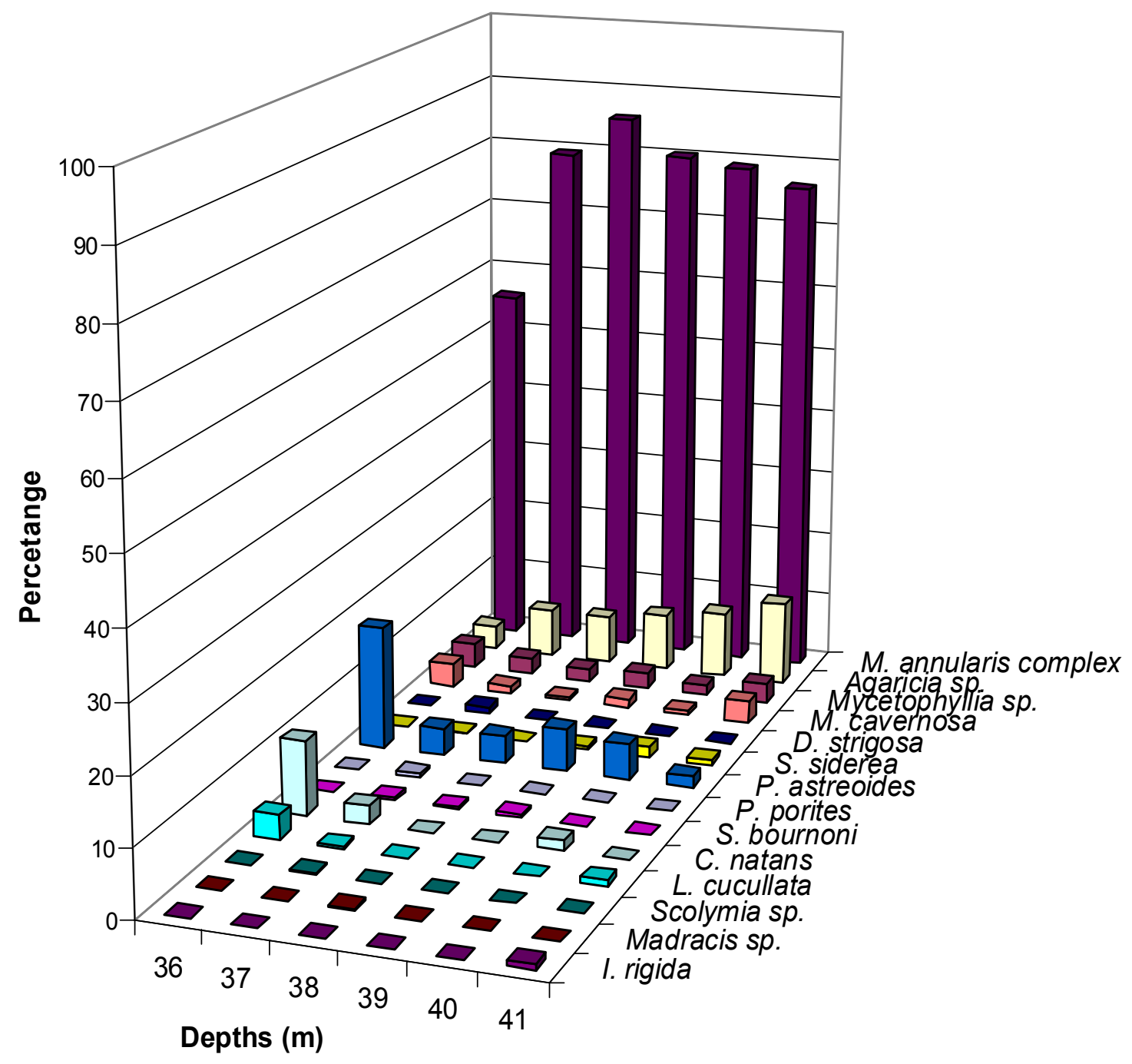

Figure 8. 


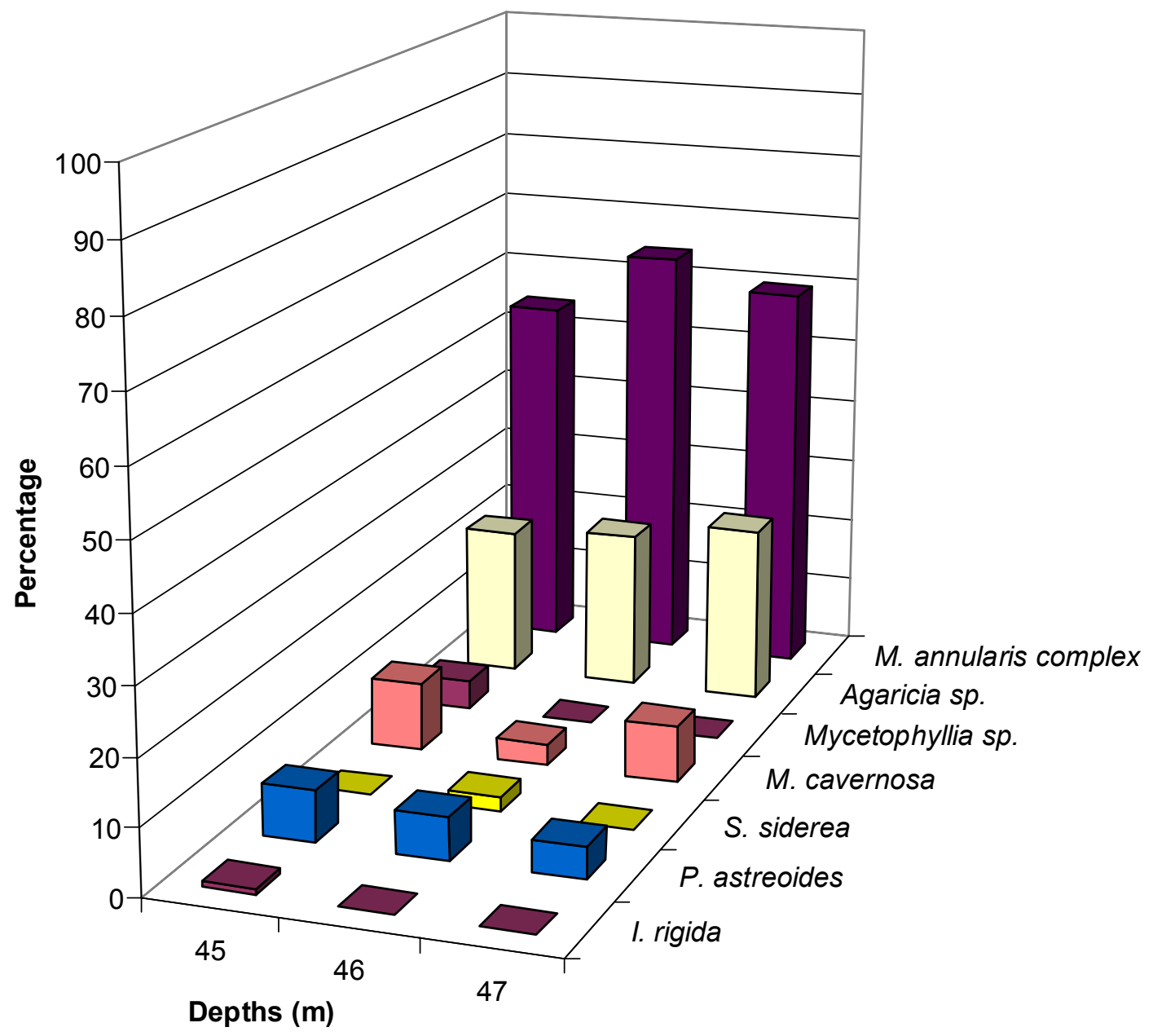

Figure 9. 


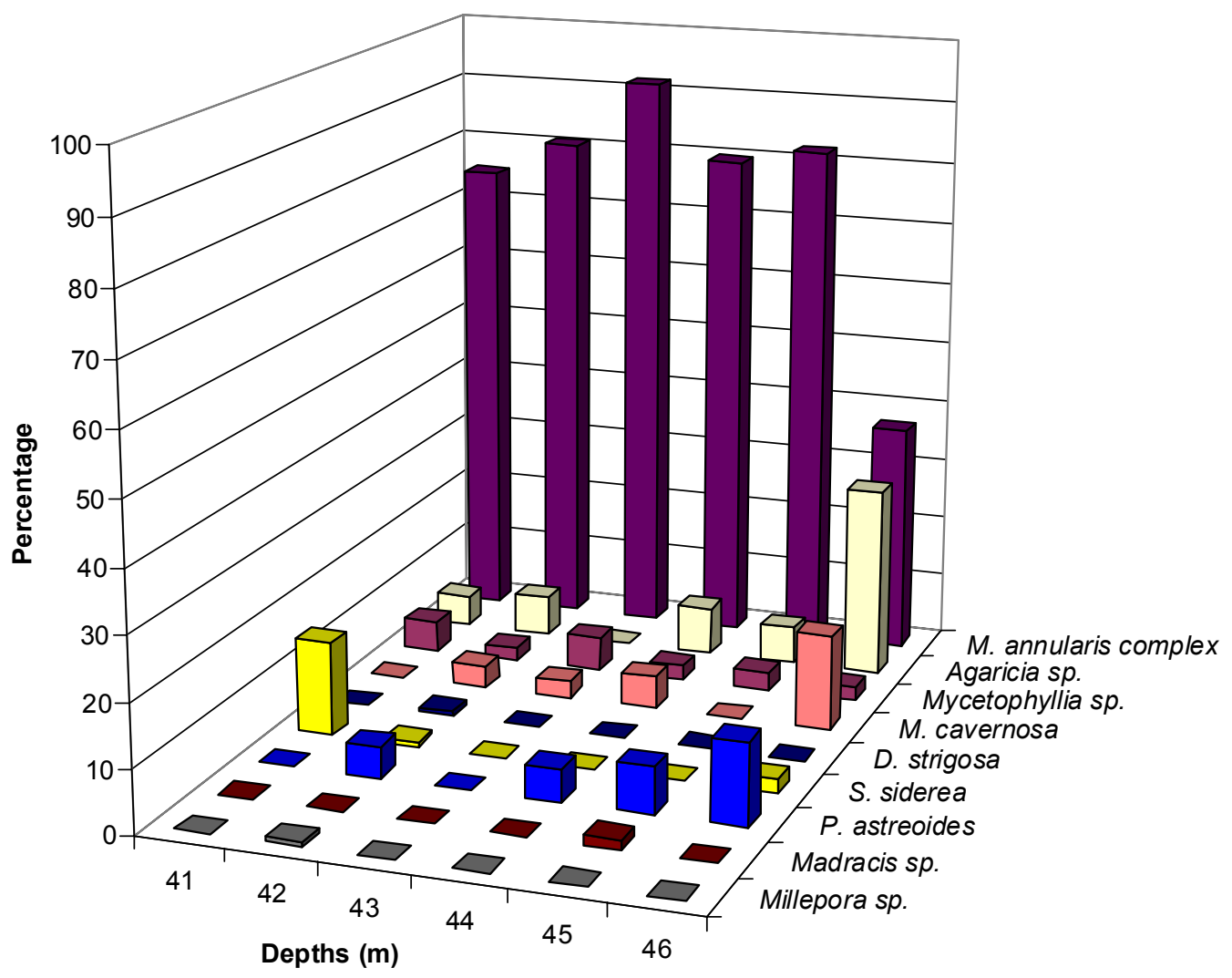

Figure 10. 